\title{
Chimeric antigen receptor T-cell therapy in glioblastoma: charging the T cells to fight
}

\author{
Craig A. Land', Phillip R. Musich', Dalia Haydar², Giedre Krenciute ${ }^{2}$ and Qian Xie ${ }^{1,3^{*}}$ (1)
}

\begin{abstract}
Glioblastoma multiforme (GBM) is the most common malignant brain cancer that invades normal brain tissue and impedes surgical eradication, resulting in early local recurrence and high mortality. In addition, most therapeutic agents lack permeability across the blood brain barrier (BBB), further reducing the efficacy of chemotherapy. Thus, effective treatment against GBM requires tumor specific targets and efficient intracranial drug delivery. With the most recent advances in immunotherapy, genetically engineered T cells with chimeric antigen receptors (CARs) are becoming a promising approach for treating cancer. By transducing T lymphocytes with CAR constructs containing a tumorassociated antigen (TAA) recognition domain linked to the constant regions of a signaling T cell receptor, CART cells may recognize a predefined TAA with high specificity in a non-MHC restricted manner, and is independent of antigen processing. Active T cells can travel across the BBB, providing additional advantage for drug delivery and tumor targeting. Here we review the CAR design and technical innovations, the major targets that are in pre-clinical and clinical development with a focus on GBM, and multiple strategies developed to improve CART cell efficacy.
\end{abstract}

Keywords: Chimeric antigen receptors, CAR, T-cell therapy, Glioblastoma, Cellular immunotherapy

\section{Background}

Glioblastoma (GBM), WHO grade IV glioma, is the most devastating brain tumor in adults [1]. The intrinsic capability of single tumor cells to invade normal brain tissue impedes surgical eradication, predictably resulting in early local recurrence and death. Current treatment options for GBM include maximal surgical removal, radiotherapy and chemotherapy. However, the overall survival rate has not changed significantly over the past decade.

Adoptive cell transfer (ACT) using autologous lymphocytes for treating cancer started in 1988 with metastatic melanoma patients [2]. While early trials reported an overall response in approximately $34 \%$ of patients [3], subsequent studies demonstrated that lymphodepletion prior to ACT may significantly improve the response

*Correspondence: xieq01@etsu.edu

${ }^{1}$ Department of Biomedical Sciences, Quillen College of Medicine, East Tennessee State University, Johnson City, TN 37614, USA

Full list of author information is available at the end of the article rates to about $50 \%$ of patients $[4,5]$. During the same period, genetically engineered $\mathrm{T}$ cell receptors (TCR) were explored to achieve robust $\mathrm{T}$ cell responses which ultimately led to the emergence of chimeric antigen receptor (CAR) T-cell therapy [6, 7]. In 2017, CD19-CAR (tisagenlecleucel) became the first FDA-approved CAR-T cell therapy for treating patients with relapsed or refractory B cell acute lymphoblastic leukemia (ALL) [8].

The first ACT-based attempts for GBM therapy started about 40 years ago when several case reports showed that autologous leukocyte infusion into the resection cavity at the time of tumor resection may improve patient's survival without toxicity [9-11]. However, these approaches lacked specificity. To overcome this, genetic engineered $\mathrm{T}$ cells have been generated to specifically target brain tumor associated antigens (TAA) and have shown promising pre-clinical results. For GBM, interleukin-13 receptor alpha 2 (IL13R $\alpha 2)$ became the first CAR T-cell target tested in the clinic for its specific overexpression in tumors but not in normal tissues [12]. Epidermal growth factor receptor variant III (EGFRvIII) [13], human

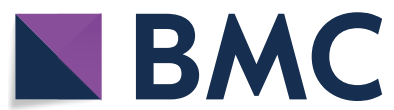

(c) The Author(s) 2020. This article is licensed under a Creative Commons Attribution 4.0 International License, which permits use, sharing, adaptation, distribution and reproduction in any medium or format, as long as you give appropriate credit to the original author(s) and the source, provide a link to the Creative Commons licence, and indicate if changes were made. The images or other third party material in this article are included in the article's Creative Commons licence, unless indicated otherwise in a credit line to the material. If material is not included in the article's Creative Commons licence and your intended use is not permitted by statutory regulation or exceeds the permitted use, you will need to obtain permission directly from the copyright holder. To view a copy of this licence, visit http://creativeco mmons.org/licenses/by/4.0/. The Creative Commons Public Domain Dedication waiver (http://creativecommons.org/publicdomain/ zero/1.0/) applies to the data made available in this article, unless otherwise stated in a credit line to the data. 
epidermal growth factor 2 (HER2) [14] and erythropoietin-producing hepatocellular carcinoma A2 (EphA2) [15] were also developed as major targets for their overexpression in GBM but not in healthy brain tissues. Other newly developed targets include ganglioside 2 (GD2) [16, 17], B7-H3 [18] and chlorotoxin [19]. Although all these targets have shown promising preclinical results and are evaluated in clinical trials (see Table 1 for summary), lack of clinical efficacy indicates that genetic modifications and therapeutic combinations are required in order to achieve a better response. In this review, we will introduce the basic CAR structures and their optimizations, the major targets that are in pre-clinical and clinical development for targeting GBM, and the combination strategies to improve CAR T-cell efficacy.

\section{CAR designs and optimization Conventional CARs}

$\mathrm{T}$ cells play an essential role in cell-mediated immune responses. $\mathrm{T}$ cell activation requires two signals: (i) TCRs recognize and bind to the antigen peptides presented on the major histocompatibility complex (MHC) exposed on the surface of antigen-presenting cells or tumor cells, and (ii) $\mathrm{T}$ cell co-stimulatory signaling modules, such as CD28, 4-1BB and OX40, which bind to the ligands expressed on antigen-presenting cells. It is well accepted that $T$ cells play a crucial role in immune surveillance, a function to detect and eliminate tumor cells from the host. Compared to the TCR (Fig. 1a), a CAR is a synthetic molecule designed to express an antigen recognition domain which is usually a single-chain variable fragment $(\mathrm{scFv})$ or a ligand specific for one TAA [20, 21]. This ectodomain is linked via a hinge and spacer to the transmembrane domain and an intracellular signaling domain. The endodomain of the CAR consists of CD3 $\zeta$ activation domain (1st generation CAR) and one or two co-stimulatory domain such as CD28, 4-1BB, or OX40 (2nd or 3rd generation CAR). While first generation CAR $\mathrm{T}$ cells had limited longevity and tumor killing efficacy in vivo [6], the second and third generation CAR $\mathrm{T}$ cells showed improved proliferation and effector function [22]. The 4th generation of CARs further compose additional genetic modifications that allow the release of transgenic proteins of interest (POI), such as cytokines, to enhance the CAR $\mathrm{T}$ cell expansion and survival [23] (Fig. 1b). Most importantly, with this design, CAR T cell can be re-directed to target specific tumor cells via $\mathrm{T}$ cellmediated multi-functional killing activities independent of MHC expression levels (Fig. 1c). Loss of MHC class I expression in tumor cells is a common mechanism leading to tumor escape and resistance to $\mathrm{T}$ cell immunity [24]. The fact that CAR $\mathrm{T}$ cells can recognize and bind to the TAAs unrestricted to MHC class I expression is making the CAR T-cell therapy an attractive approach for anti-cancer therapeutics.

\section{Universal CARs}

CAR $\mathrm{T}$ cells are showing promising anti-tumor activity against solid and brain tumors, however, the generation of a CAR targeting a novel tumor antigen is complicated and time consuming. It is well established that every new antigen-recognition domain has to be tested with multiple co-stimulatory domains. Even if well-defined and characterized, signaling domains might not be fully functional when testing with a new antigen-recognition domain. In addition, multiple studies show that the hinge and transmembrane domains also influence the function of an antigen-specific CAR T cell [25-27]. One way to overcome these challenges is to create a universal CAR (uCAR). Indeed, several groups have reported generation of uCARs. By engineering the CAR vector to express an antigen-recognition domain specific for fluorescein isothiocyanate (FITC), Tamada et al. [28] has reported an anti-FITC uCAR which further binds to FITC-tagged monoclonal antibody specific to HER2, or CD20 (Fig. 2a). Most importantly, the activity of the anti-FITC uCAR can be attenuated by additional injection of FITC-IgG, thus providing a safety switch when the risk of toxicity increases. Their study demonstrates that anti-tag CAR may elicit a potent anti-tumor activity in vitro and in vivo. However, it is not clear if such a design affects CAR $\mathrm{T}$ cell effector function when compared to a conventional CAR design.

Another uCAR study by Cho et al. [29] reported a split, universal and programmable (SUPRA) CAR system (Fig. 2b). This is a two-component system: one component is a zipFv that contains a TAA-specific $\mathrm{scFv}$ that is linked to a leucine zipper (AZip); the other component is a CAR $T$ cell that contains an extracellular leucine zipper (BZip) plus a transmembrane domain and an intracellular signaling domain (zipCAR) (Fig. 2b). After the scFv domain of the zipFv recognizes and binds to the specific TAA on tumor cells, the BZip on the zipCAR T cells can bind the AZip leucine zipper of the zipFv, leading to a fully functional CAR T-cell activation and signaling. Similar to the anti-FITC uCAR, the activity of zipCAR can be attenuated by subsequent injection of the AZip peptide. With this design, the authors generated a SUPRA CAR specific for HER2 which showed potent tumor killing activity in solid tumor settings. Moreover, they further modified this system to target multiple antigens.

While both groups demonstrated their uCAR systems for targeting HER2 experimentally, brain tumor-specific studies are warranted to evaluate whether uCARs are feasible for clinical use, given a very complex and hostile brain tumor microenvironment. In addition, the 
Table 1 Recent clinical trials of CAR T-cell therapy in glioblastoma (in alphabetical order)

\begin{tabular}{|c|c|c|c|c|}
\hline Target & Study title & Phase & Status & Institution and location \\
\hline \multicolumn{5}{|c|}{ CART-cell therapy } \\
\hline \multirow[t]{2}{*}{$\mathrm{B} 7-\mathrm{H} 3$} & $\begin{array}{l}\text { Pilot study of B7-H3 CAR-T in treating patients } \\
\text { with recurrent and refractory glioblastoma. } \\
\text { NCT04385173 }\end{array}$ & 1 & Recruiting & $\begin{array}{l}\text { Second Affiliated Hospital, School of Medicine, } \\
\text { Zhejiang University, China }\end{array}$ \\
\hline & $\begin{array}{l}\text { B7-H3 CAR-T for recurrent or refractory glioblas- } \\
\text { toma. NCT04077866 }\end{array}$ & $1 / 2$ & Recruiting & $\begin{array}{l}\text { Second Affiliated Hospital, School of Medicine, } \\
\text { Zhejiang University, China }\end{array}$ \\
\hline Chlorotoxin & $\begin{array}{l}\text { Chimeric antigen receptor (CAR) T cells with a } \\
\text { cholrotoxin tumor-targeting domain for the } \\
\text { treatment of } \mathrm{MPP}^{+} \text {recurrent or progressive } \\
\text { glioblastoma. NCT04214392 }\end{array}$ & 1 & Recruiting & City of Hope Medical Center, CA, United States \\
\hline \multirow[t]{4}{*}{ EGFRvIII } & $\begin{array}{l}\text { CART cell receptor immunotherapy targeting } \\
\text { EGFRvIll for patients with malignant gliomas } \\
\text { expressing EGFRvIII. NCT01454596 }\end{array}$ & $1 / 2$ & Completed & $\begin{array}{l}\text { National Institutes of Health Clinical Center, United } \\
\text { States }\end{array}$ \\
\hline & $\begin{array}{l}\text { Intracerebral EGFR-vl|l CAR-T cells for recurrent } \\
\text { GBM. NCT03283631 }\end{array}$ & 1 & Suspended & Duke University Medical Center, NC, United States \\
\hline & $\begin{array}{l}\text { Pilot study of autologous anti-EGFRvIII CART } \\
\text { cells in recurrent glioblastoma multiforme. } \\
\text { NCT02844062 }\end{array}$ & 1 & Unknown status & $\begin{array}{l}\text { Sanbo Brain Hospital Capital Medical University, } \\
\text { Beijing, China }\end{array}$ \\
\hline & $\begin{array}{l}\text { Memory-enriched T cells in treating patients } \\
\text { with recurrent or refractory grade III-IV glioma. } \\
\text { NCT03389230 }\end{array}$ & 1 & Recruiting & City of Hope Medical Center, CA, United States \\
\hline EphA2 & $\begin{array}{l}\text { CAR-T cell immunotherapy for EphA2 positive } \\
\text { malignant glioma patients. NCT02575261 }\end{array}$ & $1 / 2$ & Withdrawn & $\begin{array}{l}\text { Central Laboratory in Fuda Cancer Hospital, Guang- } \\
\text { dong, China }\end{array}$ \\
\hline \multirow[t]{2}{*}{ GD2 } & $\begin{array}{l}\text { C7R-GD2.CART cells for patients with GD2- } \\
\text { expressing brain tumors (GAlL-B). NCT04099797 }\end{array}$ & 1 & Recruiting & Baylor College of Medicine, TX, United States \\
\hline & $\begin{array}{l}\text { Personalized chimeric antigen receptor T cell } \\
\text { immunotherapy for patients with recurrent } \\
\text { malignant gliomas. NCT03423992 }\end{array}$ & 1 & Recruiting & Xuanwu Hospital, Beijing, China \\
\hline \multirow[t]{2}{*}{ HER2 } & $\begin{array}{l}\text { Intracranial injection of NK-92/5.28.z cells in } \\
\text { patients with recurrent HER2-positive glioblas- } \\
\text { toma. NCT03383978 }\end{array}$ & 1 & Recruiting & $\begin{array}{l}\text { Senckenberg Institute of Neurooncology, Frankfurt, } \\
\text { Germany }\end{array}$ \\
\hline & $\begin{array}{l}\text { CMV-specific cytotoxic T lymphocytes express- } \\
\text { ing CAR targeting HER2 in patients with GBM. } \\
\text { NCT01109095 }\end{array}$ & 1 & Completed & Baylor College of Medicine, TX, United States \\
\hline \multirow[t]{2}{*}{ IL13Ra2 } & $\begin{array}{l}\text { Genetically modified T cells in treating patients } \\
\text { with recurrent or refractory malignant glioma. } \\
\text { NCT02208362 }\end{array}$ & 1 & Recruiting & City of Hope Medical Center, CA, United States \\
\hline & $\begin{array}{l}\text { Phase I study of cellular immunotherapy for recur- } \\
\text { rent/refractory malignant glioma using intratu- } \\
\text { moral infusions of GRm13Z40-2, an allogeneic } \\
\text { CD8 }{ }^{+} \text {cytolitic T-cell line genetically modified } \\
\text { to express the IL 13-Zetakine and HyTK and to } \\
\text { be resistant to glucocorticoids, in combination } \\
\text { with interleukin-2. NCT01082926 }\end{array}$ & 1 & Completed & City of Hope Medical Center, , CA, United States \\
\hline \multicolumn{5}{|c|}{ CART-cell therapy in combination with chemotherapy } \\
\hline EGFRvIll & $\begin{array}{l}\text { Immunogene-modified T (IgT) cells against glio- } \\
\text { blastoma multiforme. NCT03170141 }\end{array}$ & 1 & Enrolling by invitation & $\begin{array}{l}\text { Shenzhen Geno-immune Medical Institute, Guang- } \\
\text { dong, China }\end{array}$ \\
\hline \multicolumn{5}{|c|}{ CART-cell therapy in combination with immune check point inhibitors } \\
\hline EGFRvIII & $\begin{array}{l}\text { CART-EGFRvIII + pembrolizumab in GBM. } \\
\text { NCT03726515 }\end{array}$ & 1 & Active, not recruiting & $\begin{array}{l}\text { Abramson Cancer Center of the University of Penn- } \\
\text { sylvania, PA, United States }\end{array}$ \\
\hline IL13Ra2 & $\begin{array}{l}\text { IL13Ralpha2-targeted chimeric antigen receptor } \\
\text { (CAR) T cells with or without nivolumab and } \\
\text { ipilimumab in treating patients with recurrent } \\
\text { or refractory glioblastoma. NCT04003649 }\end{array}$ & 1 & Recruiting & City of Hope Medical Center, CA, United States \\
\hline
\end{tabular}




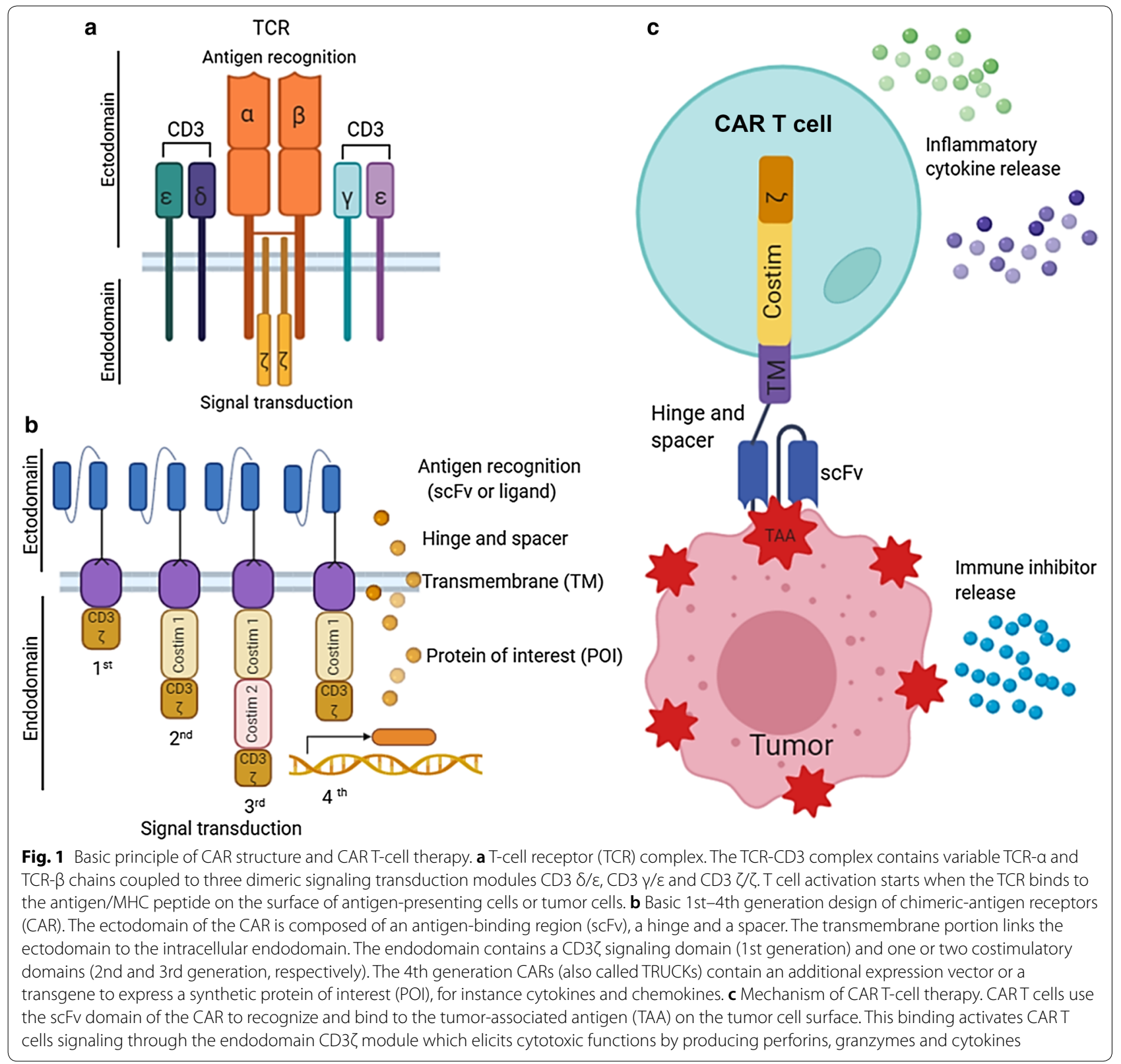

biological activity of a uCAR requires a stable complex formed by three components instead of two in traditional CARs, raising the concerns of stability and functional activities when tested in vivo. Finally, future studies should evaluate carefully the safety of uCARs as both systems contain immunogenic molecules such as FITC and leucine zippers.

\section{CARs targeting multiple antigens}

Despite the increasing number of targets being tested in clinical trials (Table 1), CAR T cells have failed to completely eradicate brain tumors. A major limitation of a single-antigen targeting CAR T-cell therapy for GBM is the inherent heterogeneity and plasticity of the tumor cells, allowing some cells to escape CAR $\mathrm{T}$ cell killing due to the loss of the targeted antigen. As a result, single antigen-targeting CAR $\mathrm{T}$ cells fail to completely eradicate brain tumors resulting in antigen-negative relapses as demonstrated by pre-clinical and clinical studies [30]. Such relapses prompted investigators to devise strategies and design CARs that can target multiple TAAs, including bi-specific, trivalent, tandem, split, and synNotch CARs (Fig. 2c-g). Among them, the first three strategies have been explored for targeting brain tumors. 

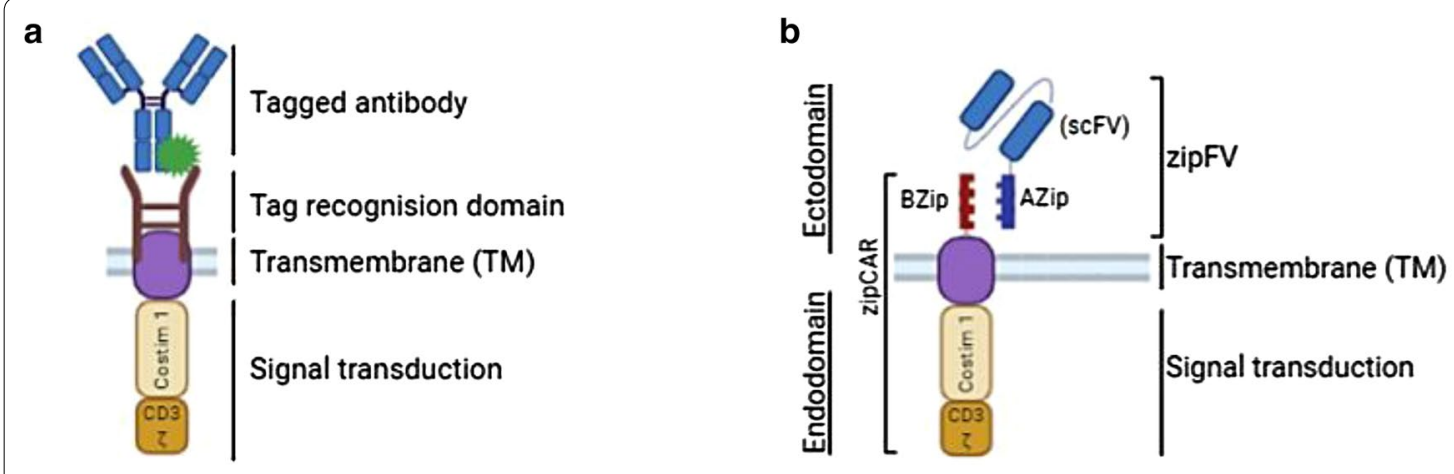

c Bi-specific CAR

d Trivalent CAR

e TanCAR
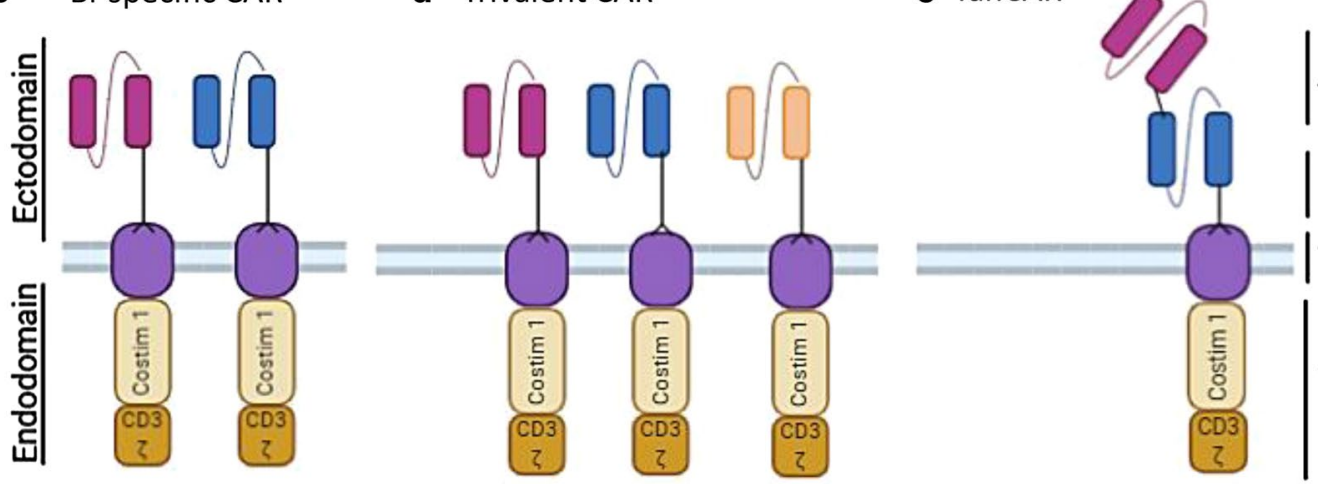

Antigen binding

f

Split CAR
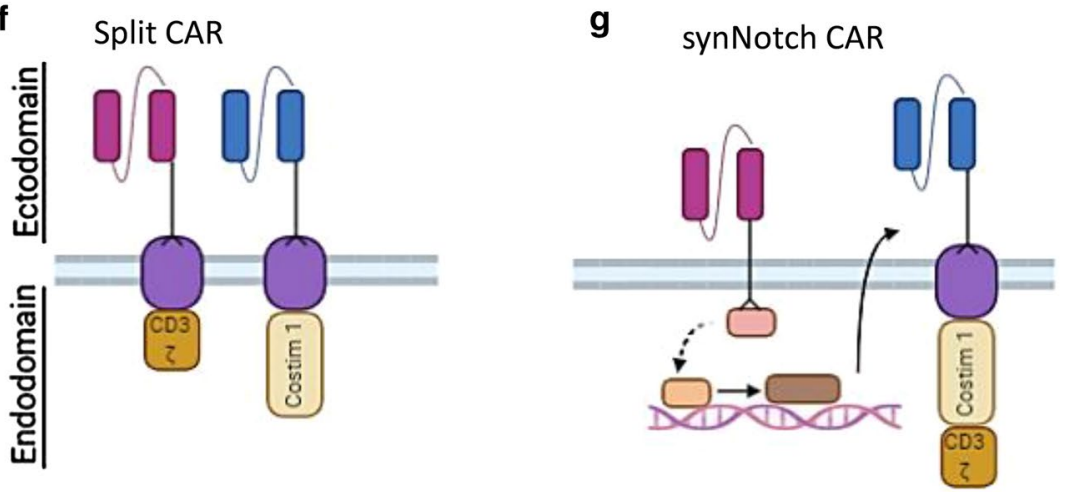

Antigen binding

Hinge and spacer

|Transmembrane (TM)

Signal transduction

Fig. 2 Optimized CAR designs. a The anti-tag UCAR is designed to express an antigen recognition domain specific for a tag (often FITC) molecule attached to a monoclonal antibody specific to the TAA on the surface of tumor cells. $\mathbf{b}$ SUPRA CAR is composed of two parts: the zipFv component consists of a scFv specific for the TAA to be targeted and a leucine zipper (AZip). The second component is zipCAR-T cell expressing a CAR with an extracellular leucine zipper (BZip). The zipFv binds to the TAA via the sCFv domain and to the zipCAR via binding of the AZip and BZip leucine zipper domains, leading to CART cell activation. $\mathbf{c}, \mathbf{d}$ Bi-specific or trivalent CART cells are designed to co-express two or three CARs within the same cell that are directed to two or three different brain TAAs, respectively. Alternatively, two or three different CART cell populations could be pooled together to simultaneously target multiple TAAs on the tumor cell surface. e Tandem CAR is composed of two or more scFvs in tandem followed by hinge, transmembrane and signaling domains. Binding of either one or more TAAs may fully activate T cell signaling and function. $\mathbf{f}$ Split CAR is designed to co-express two different CARs for targeting two different TAAs. One CAR contains the CD3Z signal and the other contains the co-stimulation signal. Binding to both TAAs is required for CART cell activation. $\mathbf{g}$ The activation of a synNotch CART cell requires two TAAs be present on the cancer cell surface and occurs in two steps: (1) the synNotch receptor recognizes and binds to the first antigen, leading to release of a transcription activator for the CAR transcription; and (2) the CAR recognizes and binds to the second antigen, leading to full CART cell activation. Only when both antigens are present will the T cells be activated and kill the target tumor cells

Bi-specific CAR T cells are generated by either double transduction of two CARs that are directed against two different brain TAA (co-expression) or by pooling two different CAR $\mathrm{T}$ cell populations (pooled CAR T cells) (Fig. 2c). Hedge et al. [31] generated $\mathrm{T}$ cells by (i) individually expressing HER2- and IL13Ra2-specific CARs or 
(ii) co-expressing both CARs, one targeting each antigen. They revealed that both approaches elicit an adequate anti-tumor response and, most importantly, prevented antigen escape in GBM in vitro and in vivo. Moreover, T cells co-expressing HER2- and IL13Ra2-CARs showed better anti-tumor response when compared to $\mathrm{T}$ cells individually expressing both CARs. The same group took it a step further and designed a trivalent CAR structure which encodes three full CAR molecules in one construct (Fig. 2d). Thus, a single transduction allowed them to express three different, separate CARs simultaneously in one $\mathrm{T}$ cell. In their study, using this method, Bielamowicz et al. [32] reported a trivalent CAR T-cell system for co-targeting HER2, IL13Ra2, and EphA2; the trivalent CAR T-cell therapy lead to a significantly better overall survival in vivo when compared to dual and single CAR $\mathrm{T}$ cells when tested in patient derived xenograft models.

Another multi-antigen targeting approach, also established by the same group, is the tandem CAR (TanCAR). Here, the CAR is composed of multiple scFvs placed in tandem followed by hinge, transmembrane and signaling domains (Fig. 2e). Hedge et al. [33] reported the development of a TanCAR designed to target HER2 and IL13R $\alpha 2$ against GBM. The authors demonstrated that TanCAR T cells have a synergistic effect in eliminating glioma cells when compared to CAR $\mathrm{T}$ cells individually targeting either IL13R $\alpha 2$ or HER2 antigens. In addition, simultaneous binding to both antigens in the TanCAR system has shown to elicited a significantly higher cytokine response when compared to that from binding to one antigen alone.

Bi-specific, trivalent, and tandem CARs are all known as "OR-gate" CARs, as binding of either CAR to its antigen is sufficient to drive full $\mathrm{T}$ cell activation. However, targeting multiple antigens may increase the safety concern especially when treating solid tumors. More specifically, many antigens that are being targeted with CAR $\mathrm{T}$ cells also are expressed in normal cells at low levels, raising the risk of on-target off-tumor toxicities. To address such issues, the split CARs, also known as "AND-gate" CARs, were designed. With this approach, $\mathrm{T}$ cells were engineered to co-express two different CARs, one containing the $\mathrm{CD} 3 \zeta$ signal and the other containing the co-stimulation signal. Recognition of a single antigen in normal cells will not be enough to activate these CAR T cells, however, only when bound to both antigens, which are overexpressed in tumor cells, would the $\mathrm{T}$ cells be fully activated (Fig. 2f). While not reported in GBM, Lanitis et al. [34] generated CAR $T$ cells that co-express anti-mesothelin $\mathrm{scFv}-\mathrm{CD} 3 \zeta$ and anti- $\alpha$-folate receptor $(\mathrm{FR} \alpha)$ scFv-CD28 CARs. These AND-gate CAR T cells showed weak cytokine secretion against the target cells expressing only one antigen in vitro. When tested in vivo, the mesothelin/FR $\alpha$-CAR T cells showed potent efficacy against tumors overexpressing both FR $\alpha$ and mesothelin, but not normal tissues expressing mesothelin alone.

The synNotch CAR is another "AND-gate" CAR [35]. The Notch protein is a transmembrane receptor with an intracellular domain containing a transcriptional regulator that is released from the membrane when activated by its ligand. With this mechanism, a synthetic Notch receptor (synNotch) was designed for binding to the first antigen for activation of synNotch system, which then switches-on the transcription of a CAR (synNotch CAR) to recognize and bind to the second antigen on cancer cells (Fig. 2g). Thus, overexpression of both antigens is required to provide the signal needed for CAR T cell killing and activation. While this system has showed functionality in vitro and in in vivo animal models $[36,37]$, the applications for brain tumors as well as in clinical trials have not been established.

\section{Genetic modification to improve CAR T cell persistence and safety}

Since CAR T-cell therapy showed promising but limited anti-tumor response in GBM clinical trials in 1990s, efforts have been made to improve CAR T-cell efficacy. A strategy is to further engineer $\mathrm{T}$ cells to overexpress transgenic proteins such as cytokines and chemokines that are known to stimulate $\mathrm{T}$ cell proliferation and persistence. Such CAR T cells are also known as "T cells redirected for universal cytokine-mediated killing", socalled TRUCKs or the 4th generation CARs [23] (Fig. 1b). Studies have shown that modifying CAR structures to overexpress IL-15 or constitutively active IL-7R (C7R) improved CAR $\mathrm{T}$ cell anti-tumor activity and persistence in GBM $[38,39]$. A recent study further reported that an "All-in-One" lentiviral TRUCKs which overexpress IL-12 or IL-18 dependent on CAR T cell activation improved the efficacy of GD2-CAR T cells in GBM [40]. While these additional CAR $T$ cell modifications greatly improved CAR T-cell therapy, they pose the risk of uncontrollable $\mathrm{T}$ cell proliferation resulting in potential treatment-related toxicities.

Safety and toxicity have always been a concern since CAR T-cell therapy entered the clinical trials. The major reported toxicity is cytokine release syndrome (CRS) as determined by a rapid and sustained cytokine release including IL-2, IL-6, IL-10 and IFN $\gamma$ following T cell activation and expansion [41-43]. However, great progress has been achieved since tocilizumab, an FDA-approved anti-IL- 6 antibody, showed rapid reversal of severe CRS syndromes, which has become the standard management [44].

As mentioned above, split CARs and synNotch CARs are designed to precisely target tumor cells rather than 
normal tissues, reducing the risk of toxicity. A more specific approach to eliminate unintended adverse effects is to manage CAR T-cell survival by modifying CAR vectors to include an inducible "suicide" gene as a safety switch. For example, Stavrou et al. [45] has reported an approach using rapamycin administration to activate the expression of caspase 9 (an apoptotic protease) in CAR T cells, which may drive CAR $\mathrm{T}$ cells toward apoptosis when needed. Notably, use of the inducible caspase 9 safety switch has entered clinical trials for treating relapsed or refractory ALL (NCT03016377) and B-cell lymphoma (NCT03696784). While severe toxicity has not been reported in GBM clinical trials, methods are being developed to avoid potential risks. Rituximab is a mono-clonal antibody that targets CD20 cells and leads to the depletion of B lymphocytes. To reduce the potential toxicity of targeting EphA2 in GBM, Yi et al. [46] showed that using CD20 as a tag in the CAR vector not only served as a selection marker for determining CAR T-cell transduction efficacy using flow cytometry, but also acted as a safety switch. Upon stimulation with rituximab, the activated CAR T cells can be efficiently eliminated within $24 \mathrm{~h}$ of treatment. Other safety switches include EGFR (targeted by cetuximab) [47, 48], and herpes simplex virus thymidine kinase (targeted by ganciclovir) [49].

\section{CAR T-cell therapeutic targets for GBM}

\section{CAR T cell targets that are in clinical trials against GBM}

CAR $\mathrm{T}$ cell targets for brain tumors that have been evaluated pre-clinically and in early phase clinical trials are IL13R $\alpha 2$, EGFRvIII, HER2, EphA2, GD2, B7-H3 and chlorotoxin. Below we discuss each of these targets by reviewing their biology and clinical trial outcomes (Table 1).

\section{IL13Ra2}

Interleukin-13 receptor alpha 2 (IL13R $\alpha 2)$ overexpression occurs in over $75 \%$ of GBM tumors, and is associated with invasive glioma growth and poor prognosis [50]. In normal cells, IL-13 binds to IL13R $\alpha 1$ monomers with low affinity, forming a heterodimer with IL4R $\alpha$, followed by activating STAT6 to induce the pro-apoptosis activity. However, in glioma, IL13R $\alpha 2$ binds to IL-13 with higher affinity, allowing for sequestration of IL-13 away from IL13R $\alpha 1$ [51, 52]. The fact that IL13R $\alpha 2$ is specifically overexpressed in GBM but not normal tissue and with higher affinity binding sites than IL13R $\alpha 1$ has made it the first CAR T cell target for GBM. Brown et al. have reported that administration of IL13R $\alpha 2$-specific CAR $\mathrm{T}$ cells into the post-surgical cavity of GBM patients resulted in a 7.5-month regression period with a median overall survival of 11 months without severe toxicity [50, 53]. Despite the initial positive response in clinical trials,
IL13R $\alpha 2$-specific CAR T-cell therapy is being challenged by tumor recurrence due to antigen loss and limited $\mathrm{T}$ cell persistence [50]. Thus, methods aiming at improving IL13Ra2-specific CAR T-cell efficacy have been evaluated [38]. In addition, evaluation of the combination therapy of IL13R $\alpha 2$-specific CAR T cells with the immune checkpoint inhibitors (ICI), such as nivolumab and ipilimumab, are in clinical trials (NCT04003649).

\section{EGFRvIII}

EGFR is a well-known receptor tyrosine kinase (RTK) involved in cancer initiation and progression. The EGFRvIII is the most common EGFR mutation that occurs in about $45 \%$ of GBM patients. EGFRvIII arises from the deletion of exons $2-7$ and has a truncated extracellular domain. This mutation causes constitutive activation of RTK/RAS/AKT signaling which is enhanced in $88 \%$ of GBM patients [54]. EGFRvIII is specific to GBM and is not found in normal tissues. EGFRvIII targeting inhibitors failed to show significant clinical efficacy in GBM patients mainly due to signaling bypass, in which inhibition of EGFR vIII pathway leads to activation of other RTKs, providing a good reason for further developing EGFR vIII-CAR T-cell therapy [55]. O'Rourke et al. [41] reported the first study in humans of intravenous delivery of a single dose of EGFRvIII-CAR T cells in 10 recurrent GBM patients which showed safety and limited anti-tumor response as well as targeted antigen downregulation. Goff et al. [56] reported a pilot phase I trial with third generation EGFRvIII-CAR $\mathrm{T}$ cells administered after lymphodepleting chemotherapy and intravenous interleukin-2 injections. This study did not show significant toxicity but failed to show clinical efficacy. Another design of EGFRvIII-CAR $\mathrm{T}$ cell using humanized $\mathrm{scFv}$ again proved safe but also failed to show clinical benefit [41, 57]. Currently, there are six EGFRvIII-CAR T cell clinical trials ongoing with two in combination with chemotherapy or ICI (Table 1).

\section{HER2}

HER2 is a member of the EGFR family, also named as ERBB2. Increased levels of HER2 protein in GBM patients is linked to poor survival [14, 58, 59]. Unlike EGFRvIII, which is unique to GBM, HER2 is overexpressed in many cancer types including breast, ovarian and GBM; it also is expressed in some normal tissues, leading to safety concerns. An early case report with HER2-CAR T cell therapy has documented a metastatic colon cancer patient who experienced respiratory distress within 15 min of HER2-targeting CAR T cell administration and died 5 days after treatment. Serum samples after cell infusion showed marked increases in interferon $\gamma(\mathrm{IFN} \gamma)$, granulocyte macrophage-colony stimulating 
factor (GM-CSF), tumor necrosis factor-alpha (TNFalpha), interleukin- 6 and -10 (IL-6 and IL-10), consistent with a cytokine storm [60]. Since then, efforts have been made to overcome these safety concerns [61]. Liu et al. [62] showed that lowering the binding affinity between $\mathrm{scFv}$ and HER2 may increase the differential binding of CAR $T$ cells to tumor versus normal tissue in preclinical cancer models, providing a good strategy for targeting the antigens that are not specific to solid tumors. A more recent clinical trial (NCT00902044) reported no significant toxicities of a second generation HER2-specific CAR T-cell therapy for sarcoma [63]. Compared with the original 4D5 HER2-CAR which binds to the juxtamembrane region of HER2 protein and caused severe toxicity, this trial used a FRP5-HER2 CAR which recognizes a discontinuous epitope between residues 11-169 of HER2 that is more distant from the cell surface. Thus, the binding site of the epitope also determines the activity of the CARs. As for GBM, investigators at Baylor College of Medicine have conducted a clinical trial (NCT01109095) to evaluate the safety and efficacy of HER2-specific CARs using virus-specific T cells (CAR-VSTs) [59]; previous studies have shown that virus engineered cytotoxic $\mathrm{T}$ cells demonstrate better persistence and $\mathrm{T}$ cell expansion through appropriate co-stimulatory signaling activation [64]. In this trial, overexpression of FRP5 HER2-CARs in virus-specific $\mathrm{T}$ cells not only improved the specific targeting of HER2 ${ }^{+}$tumor cells, but also prolonged the HER2-CAR VST cell persistence and antitumor activity. While this trial has demonstrated treatment safety, the clinical benefit was limited.

\section{EphA2}

EphA2 protein is overexpressed in gliomas and is associated with malignancy, thus it became a good molecular target in GBM $[65,66]$. Preclinical studies demonstrated that a second generation EphA2-CAR T cell induced glioma xenograft tumor regression in vivo $[46,67]$. So far one clinical trial was initiated to evaluate the safety and effectiveness of CAR $\mathrm{T}$ cell immunotherapy in treating patients with EphA2 ${ }^{+}$malignant glioma but has been withdrawn recently for unknown reason (NCT02575261).

\section{GD2}

GD2 is a glycosphingolipid expressed at low levels on the surface of healthy cells, but highly expressed on several tumor types including gliomas and is associated with increased tumor proliferation and invasion [68]. Pre-clinical studies have demonstrated a robust antigen-dependent cytokine production and killing of $\mathrm{GD} 2^{+}$-positive glioma cells in vitro and in vivo using patient-derived orthotopic xenograft models overexpressing GD2 [16, 17]. Currently, two phase I clinical trials (NCT04099797 and NCT03423992) are evaluating the safety and efficacy of GD2-specific CAR T cells in high grade glioma and diffuse intrinsic pontine glioma (DIPG).

\section{B7-H3}

B7-H3 (CD276) is an immune checkpoint molecule and a member of B7 protein superfamily. B7-H3 binds to the majority of neuroepithelial tumors but not to normal glia or tissues, making it a promising target for therapeutics [69]. Clinical trials for two mAbs targeting B7-H3 (8H9 and MGA271) have been shown to be safe and promising for metastatic CNS neuroblastoma and DIPG in children. [70, 71]. Using a B7-H3 (MGA271) 41BB C CAR, Majzner et al. [18] have reported a robust anti-tumor activity in multiple solid, liquid, and CNS tumor types. In addition, Nguyen et al. [72] demonstrated that B7-H3-specific (MGA271) CD28 C CAR-T cells have potent anti-tumor activity in U373 glioma model. To date, two GBM-related clinical trials focused on B7-H3 CAR T-cell therapy (NCT04385173, NCT04077866) are in the recruitment phase.

\section{Chlorotoxin}

Chlorotoxin (CLTX) is a 36-amino acid peptide first isolated from scorpion venom that specifically binds to GBM but not to normal tissue. Pharmacologically, CLTX binds to and blocks small-conductance chloride channels [73]. Unlike the common CARs that are designed to recognize surface TAAs to kill tumor cells, the CLTX-CAR was designed as a peptide-based CAR to recapitulate the GBM-binding potential of CLTX. With this approach, Wang et al. [19] showed that CLTX-CAR T cells mediate potent anti-GBM activity and efficiently targeted tumors lacking expression of other GBM-associated antigens, resulting in tumor regression in orthotopic xenograft GBM tumor models. Importantly, the CLTX-CAR-T cells exhibited minimal off-target effects, without showing toxicity following systemic or regional delivery into mice. Given the finding that effective targeting by CLTX-CAR $T$ cells requires cell surface expression of matrix metalloproteinase-2 (MMP2), a clinical trial has been initiated for treating $\mathrm{MMP2}^{+}$recurrent GBM (NCT04214392). More importantly, this study also opened a new avenue to repurpose the use of a natural toxin for CAR $\mathrm{T}$ cell engineering.

\section{Other potential CAR T cell targets for GBM}

While the current CAR $\mathrm{T}$ cell targets continue to be developed and improved, progress also is being made in exploring new targets specific for GBM. Below we 
review other promising brain TAAs that have been tested pre-clinically.

\section{CD70}

CD70 is a type II transmembrane protein and a member of the tumor necrosis factor family. CD70 was not detected in normal peripheral and brain tissues but was constitutively overexpressed in isocitrate dehydrogenase (IDH) wild-type primary low-grade gliomas, and GBMs in the mesenchymal subgroup and recurrent tumors. CD70 is associated with poor survival in GBM patients making it a good candidate for CAR T-cell therapy [74, 75]. Several pre-clinical studies with differently designed CD70-specific CAR-T cells have shown robust antitumor response against $\mathrm{CD} 70^{+}$mouse models $[74,76]$. While there is no current clinical trial for testing CD70specific CAR-T cells in GBM, phase I/II clinical trials are underway to study the safety and efficacy of CD70-specific CAR-T cell therapy in B cell cancers (NCT03125577, NCT04429438) as well as pancreatic, renal, breast and ovarian cancers (NCT02830724).

\section{CD133}

CD133 is a marker for self-renewing cancer stem cells (CSCs) in solid tumors. $\mathrm{CD}_{133^{+}}$tumor cells, including GBM, are known to be highly resistant to chemo- and radiotherapy. Recently, CD133 has been identified as a potential CAR T cell target for treatment of GBM. While CD133 also is expressed on hematopoietic stem and progenitor cells (HSPC), Vora et al. [77] demonstrated that intra-tumoral injections of CD133-specific CAR T cells are effective at eliminating GBM and that this treatment does not cause systemic toxicity in humanized mouse models. In addition, in a phase 1 clinical trial (NTC 02541370) CD133-specific CAR T cells showed feasibility and efficacy against advanced metastatic malignancies with no serious adverse effects, further confirming the therapeutic potential of targeting CD133 [78].

\section{MET}

MET is the receptor of hepatocyte growth factor (HGF), and a well-known RTK being developed as an anti-cancer target. HGF/MET overexpression frequently occur in GBM patients and is associated with poor prognosis $[54,79,80]$. Using a transgenic mouse model, Qin et al. [81] showed that overexpression of HGF and MET may transform neuro stem cells into glioma stem cells (GSCs), leading to GBM initiation. GBM harboring MET amplification or HGF autocrine activation are sensitive to MET inhibitors in preclinical models [82, 83], recent clinical trials further showed that a combination of MET and VEGF inhibitors (ontarzucimab plus bevacizumab vs. placebo plus bevacizumab) significantly improved progression free survival (PFS) and overall survival (OS) in the mesenchymal subtype of recurrent GBM patients with high tumor HGF expression [84]. These results suggest that MET maybe a good target for CAR T-cell therapy in GBM.

\section{Summary for CART cell targets in GBM}

Although a large number of CAR $T$ cell targets under development for treating GBM are showing promising preclinical results, limited antitumor response has been observed in clinical trials, largely due to limited $\mathrm{T}$ cell persistence and antigen-negative relapses. While technical innovations to improve the CAR T cell expansion, survival, efficacy and safety remain the key next steps to pursue, combination with other therapies also have been comprehensively considered to improve the CAR $\mathrm{T}$ cell therapy [85]. Below, we introduce the combination with ICIs as a promising approach to overcome $\mathrm{T}$ cell exhaustion which in turn may improve CAR $\mathrm{T}$ cell efficacy in clinical trials.

\section{CAR T cell therapy in combination with immune checkpoint inhibitors}

The tumor microenvironment is orchestrated by immunosuppressive cytokines, regulatory modulators and co-inhibitory receptors that regulate the responsiveness of immune cells [86]. While active CAR $\mathrm{T}$ cells elicit specific recognition and killing activities against tumor cells, the chronic exposure to tumor cells results in $\mathrm{T}$ cell exhaustion mediated by immune checkpoint pathway activation that is initiated by tumor cells, leading to a reduced ability to proliferate, produce cytokines and attack the tumor (Fig. 1c). Exhausted T cells upregulate immune inhibitory receptors, such as programmed death ligand-1 (PD-L1) and cytotoxic T lymphocyte-associated antigen 4 (CTLA-4). Blocking this immune suppressive signaling has led to the development of ICIs such as nivolumab and durvalumab (PD-1/PD-L1 inhibitors) and ipilimumab (CTLA-4 inhibitors). These ICIs are FDAapproved for treating several types of cancer including melanoma, hepatocellular carcinoma and lymphoma and have shown significant clinical results [87]. Since ICIs eliminate $\mathrm{T}$ cell exhaustion, combining their use may further enhance CAR T-cell therapy efficacy through extended $\mathrm{T}$ cell proliferation and sustained tumor-killing activity. A recent case report has shown that administration of the PD-1/PD-L1 inhibitor pembrolizumab after CD19-specific CAR T-cell therapy in refractory diffuse large B-cell lymphoma induced a clinically significant antitumor response, suggesting that the PD-1 pathway may be critical in determining the response to CARmodified T-cell immunotherapy [88]. However, despite the promising clinical results in other types of cancer, the 
use of ICIs in GBM clinical trials remain controversial. Nivolumab, a PD-1/PD-L1 inhibitor, failed to prolong overall survival of patients with recurrent GBM, leading to a discussion of whether ICIs may benefit GBM patients after all [89-91]. Nevertheless, a recent trial with 35 patients with recurrent, surgically-removable GBM showed that patients who receive neoadjuvant PD-1 blockade, with continued adjuvant therapy following surgery had significantly better overall survival compared to those who received adjuvant or post-surgical PD-1 blockade alone [92]. Another study also suggests that combination of local chemotherapy with PD-1 blockade enhanced antigen-specific $\mathrm{T}$ effector cell expansion and improves survival in GBM models [93]. These studies suggest that anti-PD-1 blockade alone may not directly benefit GBM patients but may improve the efficacy of other therapeutics when used in combination. Currently, clinical trials are on-going to evaluate the therapeutic efficacy of EGFRvIII-CAR (NCT03726515) and IL13R $\alpha 2-$ CAR (NCT04003649) T-cell therapy in combination with ICIs such as pembrolizumab or nivolumab in recurrent or refractory GBM patients (Table 1). We anticipate that anti-PD1 blockage may improve the CAR T-cell efficacy for treating GBM patients.

\section{Future perspectives}

Over the past decades, we have learned key principles to manage CAR T-cell efficacy: the specificity of the targeted antigen, the sufficient TCR activation by the specific antigen binding domain, the level of $\mathrm{T}$ cell activation and longevity, and the hostile micro-environment for $\mathrm{T}$ cells to penetrate, which also serves a source of immunosuppressive factors [94]. While many types of CAR T cells are now in clinical trials (Table 1), further optimization with advanced approaches are expected to improve their overall clinical efficacy.

Since genetic modification of CAR vectors is showing promising results in improving CAR T-cell efficacy, gene editing of the $T$ cell is now a new strategy to further improve CAR $\mathrm{T}$ cells. Recently, the CRISPR/Cas9 mediated gene editing system has been applied to delete or mutate checkpoint-associated genes in CAR T cells, and has shown improvement in $\mathrm{T}$ cell persistence and survival [95-97]. Using CRISPR/Cas 9-mediated deletion, Ren et al. [95] generated CD19-CAR T cells simultaneously deficient in TCR, HLA class I molecule and PD1, which showed more potent antitumor activities than non-edited CAR $\mathrm{T}$ cells when tested in xenograft mouse models. Notably, the TCR and HLA class I double-deficient $\mathrm{T}$ cells further reduced MHC restriction and eliminated alloreactivity and potential graft-versushost disease (GVHD), thus making the strategy particularly useful for treating different patients. A different study using CRISPR/Cas9-mediated deletion of TCR $\alpha$ subunit constant (TRAC) region, beta-2 microglobulin (B2M) and PD-1 also showed profound anti-tumor activity in vivo [97]. Recently, Li et al. [98] investigated the approaches to improve CAR $\mathrm{T}$ transduction efficacy and CRISPR/Cas9 mediated PD-1 deletion using a 2-in-1 lentivirus vector and found that blocking anti-viral signaling in human primary $\mathrm{T}$ cells enhanced lentiviralmediated transduction efficacy of a combinatory CAR/ CRISPR vector for targeting HER2 and inhibiting PD-1 at the same time. Most importantly, the first phase 1 clinical trial using CRISPR/Cas9 for multiplex gene editing on T cells (NCT03399448) has demonstrated safety and feasibility in three patients with refractory cancer [99]. Given that the CRISPR/Cas9 approach has been widely applied to functional gene screening and validation, it also opens a new avenue to discover and target novel modulators of immune suppression. Through CRISPR/Cas9mutagenesis screening, Wei et al. [100] have identified Regnase-1 as a major negative regulator of anti-tumor responses in $\mathrm{CD}^{+} \mathrm{T}$ cells, and that CD19-CAR $\mathrm{T}$ cells with deleted Regnase-1 showed greater longevity and a more vigorous anti-tumor response in B16 ovarian and B6 melanoma mouse models. We anticipate that future GBM-specific studies also will explore these novel ideas and approaches, which hopefully will further enhance CAR T-cell proliferation, longevity and long-term antitumor activity.

\section{Conclusion}

Brain tumors are considered one of the "most-difficultto- treat" solid tumors. With the most recent advances in immunotherapy, the CAR T-cell therapy has become a revolutionary approach for treating hematological malignancies and it has great potential for brain tumors. This review intends to introduce interpretations of the most relevant papers addressing the use of CAR T cells for the treatment of GBM. We discussed the CAR designs and optimization, the major CAR T cell targets in clinical trials, as well as the strategies developed to improve CAR-T cell efficacy in the context of GBM. We anticipate that future clinical trial designs will not only focus on efficacy and safety, but also on the mechanisms involved in the immune response and resistance, and that the next generation of CAR T cell therapy will become an effective and safe therapeutics for treating malignant GBM.

\footnotetext{
Abbreviations

ALL: Acute lymphoblastic leukemia; ACT: Adoptive cell transfer; BBB: Blood brain barrier; B2M: Beta-2 microglobulin; CSC: Cancer stem cells; CAR: Chimeric antigen receptors; CRISPR: Clustered regularly interspaced short palindromic repeats; Cas9: CRISPR-associated protein 9; CRS: Cytokine release syndrome; CTLA-4: Cytotoxic T lymphocyte-associated antigen 4; DIPG: Diffuse intrinsic
} 
pontine glioma; EGFRvIll: Epidermal growth factor receptor variant III; EphA2: Erythropoietin-producing hepatocellular carcinoma A2; GBM: Glioblastoma multiforme; GVHD: Graft-versus-host disease; GD2: Ganglioside 2; Fra: Folate receptor a; HGF: Hepatocyte growth factor; HER2: Human epidermal growth factor 2; IL13Ra2: Interleukin-13 receptor alpha 2; HSPC: Hematopoietic stem and progenitor cells; IDH: Isocitrate dehydrogenase; GM-CSF: Granulocyte macrophage-colony stimulating factor; TNF-alpha: Tumor necrosis factor-alpha; L: Interleukin; IFNץ: Interferon Y; MHC: Major histocompatibility complex; MMP2: Matrix metalloproteinase-2; OS: Overall survival; PD-1: Programmed death-1; PD-L1: Programmed death ligand-1; PFS: Progression free survival; scFv: Single chain variable domain of monoclonal antibodies; SUPRA CAR: Split, universal and programmable CAR; TAA: Tumor associated antigen; TCR: T cell receptors; TRAC: TCRa subunit constant; TRUCKs: T cells redirected for universal cytokine-mediated killing; UCAR: Universal CAR.

\section{Acknowledgements}

Figures were created in BioRender.com.

\section{Authors' contributions}

QX and GK developed the concept; CAL, PRM, DH, GK and QX wrote the manuscript. All authors read and approved the final manuscript.

\section{Funding}

This work was supported by the ETSU start-up fund, a Department of Defense Ideal Award CA180296 (to QX), and the Assisi Foundation of Memphis, and the American Lebanese Syrian Associated Charities (ALSAC) (to GK). QX, GK have patent applications in the field of immunotherapy.

\section{Availability of data and materials}

All data are available in the manuscript or upon request to the authors.

\section{Ethics approval and consent to participate}

Not applicable.

\section{Consent for publication}

Not applicable.

\section{Competing interests}

The authors declare that they have no competing interests.

\section{Author details}

${ }^{1}$ Department of Biomedical Sciences, Quillen College of Medicine, East Tennessee State University, Johnson City, TN 37614, USA. ${ }^{2}$ Department of Bone Marrow Transplantation and Cellular Therapy, St. Jude Children's Research Hospital, Memphis, TN 38105, USA. ${ }^{3}$ Center of Excellence for Inflammation, Infectious Disease and Immunity, Quillen College of Medicine, East Tennessee State University, Johnson City, TN 37614, USA.

\section{Received: 17 August 2020 Accepted: 30 October 2020}

Published online: 11 November 2020

\section{References}

1. Xie Q, Mittal S, Berens ME. Targeting adaptive glioblastoma: an overview of proliferation and invasion. Neuro-oncology. 2014;16(12):1575-84.

2. Rosenberg SA, Packard BS, Aebersold PM, Solomon D, Topalian SL, Toy ST, Simon P, Lotze MT, Yang JC, Seipp CA, et al. Use of tumorinfiltrating lymphocytes and interleukin-2 in the immunotherapy of patients with metastatic melanoma. A preliminary report. N Engl J Med. 1988:319(25):1676-80.

3. Rosenberg SA, Yannelli JR, Yang JC, Topalian SL, Schwartzentruber DJ, Weber JS, Parkinson DR, Seipp CA, Einhorn JH, White DE. Treatment of patients with metastatic melanoma with autologous tumor-infiltrating lymphocytes and interleukin 2. J Natl Cancer Inst. 1994;86(15):1159-66.

4. Dudley ME, Wunderlich JR, Robbins PF, Yang JC, Hwu P, Schwartzentruber DJ, Topalian SL, Sherry R, Restifo NP, Hubicki AM, et al. Cancer regression and autoimmunity in patients after clonal repopulation with antitumor lymphocytes. Science. 2002;298(5594):850-4.

5. Dudley ME, Wunderlich JR, Yang JC, Sherry RM, Topalian SL, Restifo NP, Royal RE, Kammula U, White DE, Mavroukakis SA, et al. Adoptive cell transfer therapy following non-myeloablative but lymphodepleting chemotherapy for the treatment of patients with refractory metastatic melanoma. J Clin Oncol. 2005;23(10):2346-57.

6. Sadelain M. CAR therapy: the CD19 paradigm. J Clin Invest. 2015;125(9):3392-400.

7. June $\mathrm{CH}, \mathrm{O}^{\prime}$ Connor RS, Kawalekar OU, Ghassemi S, Milone MC. CART cell immunotherapy for human cancer. Science. 2018;359(6382):1361-5.

8. O'Leary MC, Lu X, Huang Y, Lin X, Mahmood I, Przepiorka D, Gavin D, Lee S, Liu K, George B, et al. FDA approval summary: tisagenlecleucel for treatment of patients with relapsed or refractory B-cell precursor acute lymphoblastic leukemia. Clin Cancer Res. 2019;25(4):1142-6.

9. Vaquero J, Martinez R, Oya S, Coca S, Barbolla L, Ramiro J, Salazar FG. Intratumoural injection of autologous lymphocytes plus human lymphoblastoid interferon for the treatment of glioblastoma. Acta Neurochir. 1989;98(1-2):35-41.

10. Steinbok P, Thomas JP, Grossman L, Dolman CL. Intratumoral autologous mononuclear cells in the treatment of recurrent glioblastoma multiforme. A phase 1 (toxicity) study. J Neurooncol. 1984;2(2):147-51.

11. Young $H$, Kaplan A, Regelson W. Immunotherapy with autologous white cell infusions ("Iymphocytes") in the treatment of recurrrent glioblastoma multiforme: a preliminary report. Cancer. 1977;40(3):1037-44.

12. Brown CE, Starr R, Aguilar B, Shami AF, Martinez C, D'Apuzzo M, Barish ME, Forman SJ, Jensen MC. Stem-like tumor-initiating cells isolated from IL13Ralpha2 expressing gliomas are targeted and killed by IL13zetakine-redirected T cells. Clin Cancer Res. 2012;18(8):2199-209.

13. Morgan RA, Johnson LA, Davis JL, Zheng Z, Woolard KD, Reap EA, Feldman SA, Chinnasamy N, Kuan CT, Song H, et al. Recognition of glioma stem cells by genetically modified T cells targeting EGFRvIII and development of adoptive cell therapy for glioma. Hum Gene Ther. 2012;23(10):1043-53.

14. Ahmed N, Salsman VS, Kew Y, Shaffer D, Powell S, Zhang YJ, Grossman RG, Heslop HE, Gottschalk S. HER2-specific T cells target primary glioblastoma stem cells and induce regression of autologous experimental tumors. Clin Cancer Res. 2010;16(2):474-85.

15. Miao H, Gale NW, Guo H, Qian J, Petty A, Kaspar J, Murphy AJ, Valenzuela DM, Yancopoulos G, Hambardzumyan D, et al. EphA2 promotes infiltrative invasion of glioma stem cells in vivo through cross-talk with Akt and regulates stem cell properties. Oncogene. 2015;34(5):558-67.

16. Mount CW, Majzner RG, Sundaresh S, Arnold EP, Kadapakkam M, Haile S, Labanieh L, Hulleman E, Woo PJ, Rietberg SP, et al. Potent antitumor efficacy of anti-GD2 CART cells in H3-K27M(+) diffuse midline gliomas. Nat Med. 2018;24(5):572-9.

17. Golinelli G, Grisendi G, Prapa M, Bestagno M, Spano C, Rossignoli F, Bambi F, Sardi I, Cellini M, Horwitz EM, et al. Targeting GD2-positive glioblastoma by chimeric antigen receptor empowered mesenchymal progenitors. Cancer Gene Ther. 2018;27:558-70.

18. Majzner RG, Theruvath JL, Nellan A, Heitzeneder S, Cui Y, Mount CW, Rietberg SP, Linde MH, Xu P, Rota C, et al. CART cells targeting $\mathrm{B} 7-\mathrm{H} 3$, a pan-cancer antigen, demonstrate potent preclinical activity against pediatric solid tumors and brain tumors. Clin Cancer Res. 2019;25(8):2560-74.

19. Wang D, Starr R, Chang WC, Aguilar B, Alizadeh D, Wright SL, Yang X, Brito A, Sarkissian A, Ostberg JR, et al. Chlorotoxin-directed CAR T cells for specific and effective targeting of glioblastoma. Sci Transl Med. 2020. https://doi.org/10.1126/scitranslmed.aaw2672.

20. Kuwana Y, Asakura Y, Utsunomiya N, Nakanishi M, Arata Y, Itoh S, Nagase F, Kurosawa Y. Expression of chimeric receptor composed of immunoglobulin-derived $V$ regions and $T$-cell receptor-derived $C$ regions. Biochem Biophys Res Commun. 1987;149(3):960-8.

21. Gross G, Waks T, Eshhar Z. Expression of immunoglobulin-T-cell receptor chimeric molecules as functional receptors with antibody-type specificity. Proc Natl Acad Sci USA. 1989;86(24):10024-8.

22. Abate-Daga D, Davila ML. CAR models: next-generation CAR modifications for enhanced T-cell function. Mol Ther Oncolytics. 2016;3:16014.

23. Chmielewski M, Abken H. TRUCKs: the fourth generation of CARs. Expert Opin Biol Ther. 2015;15(8):1145-54.

24. Garrido F, Aptsiauri N, Doorduijn EM, Garcia Lora AM, van Hall T. The urgent need to recover MHC class I in cancers for effective immunotherapy. Curr Opin Immunol. 2016;39:44-51. 
25. Watanabe N, Bajgain P, Sukumaran S, Ansari S, Heslop HE, Rooney CM, Brenner MK, Leen AM, Vera JF. Fine-tuning the CAR spacer improves T-cell potency. Oncoimmunology. 2016;5(12):e1253656.

26. Morin SO, Giroux V, Favre C, Bechah Y, Auphan-Anezin N, Roncagalli R, Mege JL, Olive D, Malissen M, Nunes JA. In the absence of its cytosolic domain, the CD28 molecule still contributes to T cell activation. Cell Mol Life Sci. 2015;72(14):2739-48.

27. Guedan S, Posey AD Jr, Shaw C, Wing A, Da T, Patel PR, McGettigan SE, Casado-Medrano V, Kawalekar OU, Uribe-Herranz M, et al. Enhancing CART cell persistence through ICOS and 4-1BB costimulation. JCI Insight. 2018;3(1):e96976.

28. Tamada K, Geng D, Sakoda Y, Bansal N, Srivastava R, Li Z, Davila E. Redirecting gene-modified T cells toward various cancer types using tagged antibodies. Clin Cancer Res. 2012;18(23):6436-45.

29. Cho JH, Collins JJ, Wong WW. Universal chimeric antigen receptors for multiplexed and logical control of T cell responses. Cell. 2018;173(6):1421.e4116-1438.e1411.

30. Han X, Wang Y, Wei J, Han W. Multi-antigen-targeted chimeric antigen receptor T cells for cancer therapy. J Hematol Oncol. 2019;12(1):128.

31. Hegde M, Corder A, Chow KK, Mukherjee M, Ashoori A, Kew Y, Zhang YJ, Baskin DS, Merchant FA, Brawley VS, et al. Combinational targeting offsets antigen escape and enhances effector functions of adoptively transferred T cells in glioblastoma. Mol Ther. 2013;21(11):2087-101.

32. Bielamowicz K, Fousek K, Byrd TT, Samaha H, Mukherjee M, Aware N, Wu MF, Orange JS, Sumazin P, Man TK, et al. Trivalent CART cells overcome interpatient antigenic variability in glioblastoma. Neuro-oncology. 2018;20(4):506-18.

33. Hegde M, Mukherjee M, Grada Z, Pignata A, Landi D, Navai SA, Wakefield A, Fousek K, Bielamowicz K, Chow KK, et al. Tandem CART cells targeting HER2 and IL13Ralpha2 mitigate tumor antigen escape. J Clin Invest. 2016:126(8):3036-52.

34. Lanitis E, Poussin M, Klattenhoff AW, Song D, Sandaltzopoulos R, June $\mathrm{CH}$, Powell DJ Jr. Chimeric antigen receptor T Cells with dissociated signaling domains exhibit focused antitumor activity with reduced potential for toxicity in vivo. Cancer Immunol Res. 2013;1(1):43-53.

35. Roybal KT, Rupp L, Morsut L, Walker WJ, McNally KA, Park JS, Lim WA. Precision tumor recognition by $T$ cells with combinatorial antigensensing circuits. Cell. 2016;164(4):770-9.

36. Morsut L, Roybal KT, Xiong X, Gordley RM, Coyle SM, Thomson M, Lim WA. Engineering customized cell sensing and response behaviors using synthetic notch receptors. Cell. 2016;164(4):780-91.

37. Roybal KT, Williams JZ, Morsut L, Rupp LJ, Kolinko I, Choe JH, Walker WJ, McNally KA, Lim WA. Engineering T cells with customized therapeutic response programs using synthetic notch receptors. Cell. 2016;167(2):419.e416-432.e416.

38. Krenciute G, Prinzing BL, Yi Z, Wu MF, Liu H, Dotti G, Balyasnikova IV, Gottschalk S. Transgenic expression of IL15 improves antiglioma activity of IL13Ralpha2-CART cells but results in antigen loss variants. Cancer Immunol Res. 2017;5(7):571-81.

39. Shum T, Omer B, Tashiro H, Kruse RL, Wagner DL, Parikh K, Yi Z, Sauer T, Liu D, Parihar R, et al. Constitutive signaling from an engineered IL7 receptor promotes durable tumor elimination by tumor-redirected $\mathrm{T}$ cells. Cancer Discov. 2017:7(11):1238-47.

40. Zimmermann K, Kuehle J, Dragon AC, Galla M, Kloth C, Rudek LS, Sandalcioglu IE, Neyazi B, Moritz T, Meyer J, et al. Design and characterization of an "all-in-one" lentiviral vector system combining constitutive anti-GD2 CAR expression and inducible cytokines. Cancers. 2020;12(2):375.

41. O'Rourke DM, Nasrallah MP, Desai A, Melenhorst J, Mansfield K, Morrissette JJD, Martinez-Lage M, Brem S, Maloney E, Shen A, et al. A single dose of peripherally infused EGFRvill-directed CART cells mediates antigen loss and induces adaptive resistance in patients with recurrent glioblastoma. Sci TransI Med. 2017;9(399):eaaa0984.

42. Maude SL, Barrett D, Teachey DT, Grupp SA. Managing cytokine release syndrome associated with novel $\mathrm{T}$ cell-engaging therapies. Cancer J. 2014:20(2):119-22.

43. Frey N, Porter D. Cytokine release syndrome with chimeric antigen receptor T cell therapy. Biol Blood Marrow Transpl. 2019;25(4):e123-7.

44. Grupp SA, Kalos M, Barrett D, Aplenc R, Porter DL, Rheingold SR, Teachey DT, Chew A, Hauck B, Wright JF, et al. Chimeric antigen receptor-modified T cells for acute lymphoid leukemia. N Engl J Med. 2013;368(16):1509-18.

45. Stavrou M, Philip B, Traynor-White C, Davis CG, Onuoha S, Cordoba S, Thomas S, Pule M. A rapamycin-activated caspase 9-based suicide gene. Mol Ther. 2018;26(5):1266-76.

46. Yi Z, Prinzing BL, Cao F, Gottschalk S, Krenciute G. Optimizing EphA2CART cells for the adoptive immunotherapy of glioma. Mol Ther Methods Clin Dev. 2018;9:70-80.

47. Paszkiewicz PJ, Frassle SP, Srivastava S, Sommermeyer D, Hudecek M, Drexler I, Sadelain M, Liu L, Jensen MC, Riddell SR, et al. Targeted antibody-mediated depletion of murine CD19 CART cells permanently reverses B cell aplasia. J Clin Invest. 2016;126(11):4262-72.

48. Kao RL, Truscott LC, Chiou TT, Tsai W, Wu AM, De Oliveira SN. A cetuximab-mediated suicide system in chimeric antigen receptormodified hematopoietic stem cells for cancer therapy. Hum Gene Ther. 2019;30(4):413-28.

49. Casucci M, Nicolis di Robilant B, Falcone L, Camisa B, Norelli M, Genovese P, Gentner B, Gullotta F, Ponzoni M, Bernardi M, et al. CD44v6-targeted $T$ cells mediate potent antitumor effects against acute myeloid leukemia and multiple myeloma. Blood. 2013;122(20):3461-72.

50. Brown CE, Alizadeh D, Starr R, Weng L, Wagner JR, Naranjo A, Ostberg JR, Blanchard MS, Kilpatrick J, Simpson J, et al. Regression of glioblastoma after chimeric antigen receptor T-cell therapy. N Engl I Med. 2016;375(26):2561-9.

51. Sattiraju A, Solingapuram Sai KK, Xuan A, Pandya DN, Almaguel FG, Wadas TJ, Herpai DM, Debinski W, Mintz A. IL13RA2 targeted al pha particle therapy against glioblastomas. Oncotarget. 2017;8(26):42997-3007.

52. Thaci B, Brown CE, Binello E, Werbaneth $K$, Sampath $P$, Sengupta $S$. Significance of interleukin-13 receptor alpha 2-targeted glioblastoma therapy. Neuro-oncology. 2014;16(10):1304-12.

53. Brown CE, Badie B, Barish ME, Weng L, Ostberg JR, Chang WC, Naranjo A, Starr R, Wagner J, Wright C, et al. Bioactivity and safety of IL13Ralpha2-redirected chimeric antigen receptor CD8+ T cells in patients with recurrent glioblastoma. Clin Cancer Res. 2015;21(18):4062-72.

54. Cancer Genome Atlas Research Network. Comprehensive genomic characterization defines human glioblastoma genes and core pathways. Nature. 2008;455(7216):1061-8.

55. Chistiakov DA, Chekhonin IV, Chekhonin VP. The EGFR variant III mutant as a target for immunotherapy of glioblastoma multiforme. Eur J Pharmacol. 2017:810:70-82.

56. Goff SL, Morgan RA, Yang JC, Sherry RM, Robbins PF, Restifo NP, Feldman SA, Lu YC, Lu L, Zheng Z, et al. Pilot trial of adoptive transfer of chimeric antigen receptor-transduced T cells targeting EGFRvIll in patients with glioblastoma. J Immunother. 2019;42(4):126-35.

57. Sampson JH, Choi BD, Sanchez-Perez L, Suryadevara CM, Snyder DJ, Flores CT, Schmittling RJ, Nair SK, Reap EA, Norberg PK, et al. EGFRvIII mCAR-modified T-cell therapy cures mice with established intracerebral glioma and generates host immunity against tumor-antigen loss. Clin Cancer Res. 2014:20(4):972-84.

58. Schonfeld K, Sahm C, Zhang C, Naundorf S, Brendel C, Odendahl M, Nowakowska P, Bonig H, Kohl U, Kloess S, et al. Selective inhibition of tumor growth by clonal NK cells expressing an ErbB2/HER2-specific chimeric antigen receptor. Mol Ther. 2015;23(2):330-8.

59. Ahmed N, Brawley V, Hegde M, Bielamowicz K, Kalra M, Landi D, Robertson C, Gray TL, Diouf O, Wakefield A, et al. HER2-specific chimeric antigen receptor-modified virus-specific $\mathrm{T}$ cells for progressive glioblastoma: a phase 1 dose-escalation trial. JAMA Oncol. 2017;3(8):1094-101.

60. Morgan RA, Yang JC, Kitano M, Dudley ME, Laurencot CM, Rosenberg SA. Case report of a serious adverse event following the administration of T cells transduced with a chimeric antigen receptor recognizing ERBB2. Mol Ther. 2010;18(4):843-51.

61. Liu X, Zhang N, Shi H. Driving better and safer HER2-specific CARs for cancer therapy. Oncotarget. 2017;8(37):62730-41.

62. Liu X, Jiang S, Fang C, Yang S, Olalere D, Pequignot EC, Cogdill AP, Li N, Ramones M, Granda B, et al. Affinity-tuned ErbB2 or EGFR chimeric antigen receptor $T$ cells exhibit an increased therapeutic index against tumors in mice. Cancer Res. 2015;75(17):3596-607.

63. Ahmed N, Brawley VS, Hegde M, Robertson C, Ghazi A, Gerken C, Liu E, Dakhova O, Ashoori A, Corder A, et al. Human epidermal growth factor receptor 2 (HER2) - specific chimeric antigen receptor-modified 
T cells for the immunotherapy of HER2-positive sarcoma. J Clin Oncol. 2015;33(15):1688-96.

64. Pule MA, Savoldo B, Myers GD, Rossig C, Russell HV, Dotti G, Huls MH, Liu E, Gee AP, Mei Z, et al. Virus-specific T cells engineered to coexpress tumor-specific receptors: persistence and antitumor activity in individuals with neuroblastoma. Nat Med. 2008;14(11):1264-70.

65. Wang LF, Fokas E, Bieker M, Rose F, Rexin P, Zhu Y, Pagenstecher A, Engenhart-Cabillic R, An HX. Increased expression of EphA2 correlates with adverse outcome in primary and recurrent glioblastoma multiforme patients. Oncol Rep. 2008;19(1):151-6.

66. Wykosky J, Gibo DM, Stanton C, Debinski W. EphA2 as a novel molecular marker and target in glioblastoma multiforme. Mol Cancer Res. 2005:3(10):541-51.

67. Chow KK, Naik S, Kakarla S, Brawley VS, Shaffer DR, Yi Z, Rainusso N, Wu MF, Liu H, Kew Y, et al. T cells redirected to EphA2 for the immunotherapy of glioblastoma. Mol Ther. 2013;21(3):629-37.

68. Sorokin M, Kholodenko I, Kalinovsky D, Shamanskaya T, Doronin I, Konovalov D, Mironov A, Kuzmin D, Nikitin D, Deyev S, et al. RNA sequencingbased identification of ganglioside GD2-positive cancer phenotype. Biomedicines. 2020;8(6):142.

69. Zhou Z, Luther N, Ibrahim GM, Hawkins C, Vibhakar R, Handler MH, Souweidane MM. B7-H3, a potential therapeutic target, is expressed in diffuse intrinsic pontine glioma. J Neurooncol. 2013;111(3):257-64.

70. Souweidane MM, Kramer K, Pandit-Taskar N, Zhou Z, Haque S, Zanzonico P, Carrasquillo JA, Lyashchenko SK, Thakur SB, Donzelli $\mathrm{M}$, et al. Convection-enhanced delivery for diffuse intrinsic pontine glioma: a single-centre, dose-escalation, phase 1 trial. Lancet Oncol. 2018;19(8):1040-50

71. Kramer K, Kushner BH, Modak S, Pandit-Taskar N, Smith-Jones P, Zanzonico P, Humm JL, Xu H, Wolden SL, Souweidane MM, et al. Compartmental intrathecal radioimmunotherapy: results for treatment for metastatic CNS neuroblastoma. J Neurooncol. 2010;97(3):409-18.

72. Nguyen P, Okeke E, Clay M, Haydar D, Justice J, O'Reilly C, Pruett-Miller S, Papizan J, Moore J, Zhou S, et al. Route of $41 \mathrm{BB} / 41 \mathrm{BBL}$ costimulation determines effector function of B7-H3-CAR.CD28ZT cells. Mol Ther Oncolytics. 2020;18:202-14.

73. Dardevet L, Rani D, AzizTA, Bazin I, Sabatier JM, Fadl M, Brambilla E, De Waard M. Chlorotoxin: a helpful natural scorpion peptide to diagnose glioma and fight tumor invasion. Toxins. 2015;7(4):1079-101.

74. Jin L, Ge H, Long Y, Yang C, Chang YE, Mu L, Sayour EJ, De Leon G, Wang $\mathrm{QJ}$, Yang JC, et al. CD70, a novel target of CART-cell therapy for gliomas. Neuro-oncology. 2018;20(1):55-65.

75. Ge H, Mu L, Jin L, Yang C, Chang YE, Long Y, DeLeon G, Deleyrolle L, Mitchell DA, Kubilis PS, et al. Tumor associated CD70 expression is involved in promoting tumor migration and macrophage infiltration in GBM. Int J Cancer. 2017:141(7):1434-44.

76. Wang QJ, Yu Z, Hanada KI, Patel K, Kleiner D, Restifo NP, Yang JC. Preclinical evaluation of chimeric antigen receptors targeting CD70-expressing cancers. Clin Cancer Res. 2017;23(9):2267-76.

77. Vora P, Venugopal C, Salim SK, Tatari N, Bakhshinyan D, Singh M, Seyfrid M, Upreti D, Rentas S, Wong N, et al. The rational development of CD133-targeting immunotherapies for glioblastoma. Cell Stem Cell. 2020:26(6):832 e836-844 e836.

78. Wang Y, Chen M, Wu Z, Tong C, Dai H, Guo Y, Liu Y, Huang J, Lv H, Luo C, et al. CD133-directed CART cells for advanced metastasis malignancies: a phase I trial. Oncoimmunology. 2018;7(7):e1440169.

79. Xie Q, Bradley R, Kang L, Koeman J, Ascierto ML, Worschech A, De Giorgi V, Wang E, Kefene L, Su Y, et al. Hepatocyte growth factor (HGF) autocrine activation predicts sensitivity to MET inhibition in glioblastoma. Proc Natl Acad Sci USA. 2012;109(2):570-5.

80. Petterson SA, Dahlrot RH, Hermansen SK, Munthe SK, Gundesen MT, Wohlleben H, Rasmussen T, Beier CP, Hansen S, Kristensen BW. High levels of c-Met is associated with poor prognosis in glioblastoma. J Neurooncol. 2015;122(3):517-27.

81. Qin Y, Musket A, Kou J, Preiszner J, Tschida B, Qin A, Land C, Staal B, Kang L, Tanner K, et al. Overexpression of HGF/MET axis along with p53 inhibition induces de novo glioma formation in mice. Neuro Oncol Adv. 2020. https://doi.org/10.1093/noajnl/vdaa067.

82. Johnson J, Ascierto ML, Mittal S, Newsome D, Kang L, Briggs M, Tanner K, Marincola FM, Berens ME, Vande Woude GF, et al. Genomic profiling of a hepatocyte growth factor-dependent signature for MET-targeted therapy in glioblastoma. J Transl Med. 2015;13:306.

83. Kou J, Musich PR, Staal B, Kang L, Qin Y, Yao ZQ, Zhang B, Wu W, Tam A, Huang A, et al. Differential responses of MET activations to MET kinase inhibitor and neutralizing antibody. J Transl Med. 2018;16(1):253.

84. Cloughesy T, Finocchiaro G, Belda-Iniesta C, Recht L, Brandes AA, Pineda E, Mikkelsen T, Chinot OL, Balana C, Macdonald DR, et al. Randomized, double-blind, placebo-controlled, multicenter phase II study of onartuzumab plus bevacizumab versus placebo plus bevacizumab in patients with recurrent glioblastoma: efficacy, safety, and hepatocyte growth factor and O(6)-methylguanine-DNA methyltransferase biomarker analyses. J Clin Oncol. 2017;35(3):343-51.

85. Akhavan D, Alizadeh D, Wang D, Weist MR, Shepphird JK, Brown CE. CAR T cells for brain tumors: lessons learned and road ahead. Immunol Rev. 2019;290(1):60-84.

86. Gajewski TF, Meng Y, Blank C, Brown I, Kacha A, Kline J, Harlin H. Immune resistance orchestrated by the tumor microenvironment. Immunol Rev. 2006;213:131-45.

87. Hargadon KM, Johnson CE, Williams CJ. Immune checkpoint blockade therapy for cancer: an overview of FDA-approved immune checkpoint inhibitors. Int Immunopharmacol. 2018;62:29-39.

88. Chong EA, Melenhorst JJ, Lacey SF, Ambrose DE, Gonzalez V, Levine BL, June CH, Schuster SJ. PD-1 blockade modulates chimeric antigen receptor (CAR)-modified T cells: refueling the CAR. Blood. 2017;129(8):1039-41.

89. Khasraw M, Reardon DA, Weller M, Sampson JH. PD-1 inhibitors: do they have a future in the treatment of glioblastoma? Clin Cancer Res. 2020. https://doi.org/10.1158/1078-0432.CCR-20-1135.

90. Filley AC, Henriquez M, Dey M. Recurrent glioma clinical trial, CheckMate-143: the game is not over yet. Oncotarget. 2017;8(53):91779-94.

91. Maxwell R, Jackson CM, Lim M. Clinical trials investigating immune checkpoint blockade in glioblastoma. Curr Treat Options Oncol. 2017;18(8):51.

92. Cloughesy TF, Mochizuki AY, Orpilla JR, Hugo W, Lee AH, Davidson TB, Wang AC, Ellingson BM, Rytlewski JA, Sanders CM, et al. Neoadjuvant anti-PD-1 immunotherapy promotes a survival benefit with intratumoral and systemic immune responses in recurrent glioblastoma. Nat Med. 2019;25(3):477-86.

93. Mathios D, Kim JE, Mangraviti A, Phallen J, Park CK, Jackson CM, GarzonMuvdi T, Kim E, Theodros D, Polanczyk M, et al. Anti-PD-1 antitumor immunity is enhanced by local and abrogated by systemic chemotherapy in GBM. Sci Transl Med. 2016;8(370):370ra180.

94. Wang E, Cesano A, Butterfield LH, Marincola F. Improving the therapeutic index in adoptive cell therapy: key factors that impact efficacy. J Immunother Cancer. 2020;8(2):e001619.

95. Ren J, Liu X, Fang C, Jiang S, June CH, Zhao Y. Multiplex genome editing to generate universal CART cells resistant to PD1 inhibition. Clin Cancer Res. 2017;23(9):2255-66.

96. Ren J, Zhao Y. Advancing chimeric antigen receptor T cell therapy with CRISPR/Cas9. Protein Cell. 2017;8(9):634-43.

97. Liu X, Zhang Y, Cheng C, Cheng AW, Zhang X, Li N, Xia C, Wei X, Liu X, Wang H. CRISPR-Cas9-mediated multiplex gene editing in CAR-T cells. Cell Res. 2017:27(1):154-7.

98. Li L, Gao Y, Srivastava R, Wang W, Xiong Q, Fang Z, Pelayo A, Denson C, Goswami A, Harari-Steinfeld R, et al. Lentiviral delivery of combinatorial CAR/CRISPRi circuit into human primary T cells is enhanced by TBK1/ IKKvarepsilon complex inhibitor BX795. J TransI Med. 2020;18(1):363.

99. Stadtmauer EA, Fraietta JA, Davis MM, Cohen AD, Weber KL, Lancaster E, Mangan PA, Kulikovskaya I, Gupta M, Chen F, et al. CRISPR-engineered T cells in patients with refractory cancer. Science. 2020. https://doi. org/10.1126/science.aba7365.

100. Wei J, Long L, Zheng W, Dhungana Y, Lim SA, Guy C, Wang Y, Wang Y-D, Qian C, Xu B, et al. Targeting REGNASE-1 programs long-lived effector T cells for cancer therapy. Nature. 2019;576(7787):471-6.

\section{Publisher's Note}

Springer Nature remains neutral with regard to jurisdictional claims in published maps and institutional affiliations. 